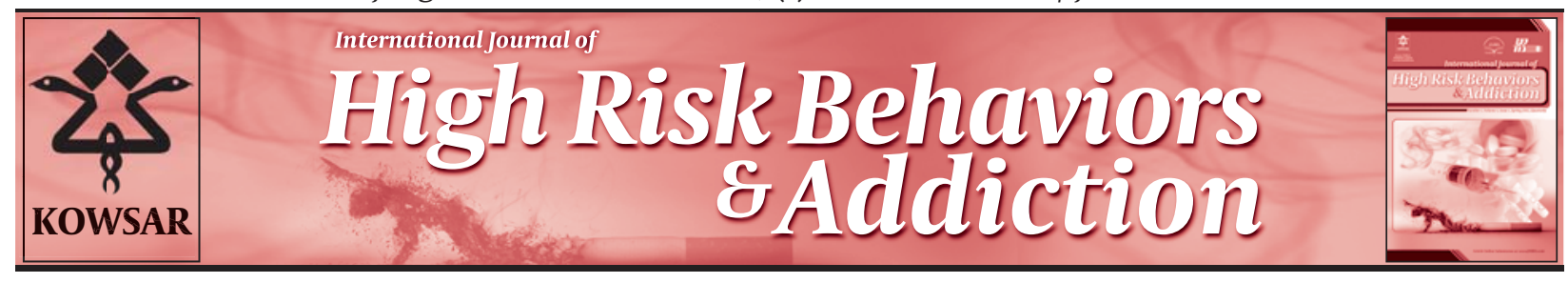

\title{
Supari Consumption is a Common Oral Habit Among Women in Chabahar City
}

\author{
Masoomeh Shirzaii ${ }^{1^{*}}$, Mahmood Sarani $^{2}$ \\ ${ }^{1}$ Department of Dentistry, Zahedan University Medical Sciences, Zahedan, IR Iran \\ 2 Department of Engineer, University of Sistan and Baluchestan, Zahedan, IR Iran
}

\section{A R T I C L E I N F O}

Article type:

Letter to Editor

Article history:

Received: 08 Dec 2011

Revised: 28 Dec 2011

Accepted: 04 Jan 2012

Keywords:

Oral Submocus Fibrosis

Mouth

Habits

Areca

\section{Dear Editor}

Chewing of areca nuts (Figure 1) in various forms is a common practice in India where areca nut products such as guthka, supari, and betel quid, with or without tobacco (pan) (Figure 2), are easily available. In India, there are regional differences in the consumption of these areca nut products. The nut contains arecoline and other alkaloids that very strongly stimulate the synthesis of collagen by fibroblasts $(1,2)$. People begin consuming areca nut products (pan, guthka, and supari) at an early age, thereby increasing the risk of oral mucosal fibrosis (OSF). OSF is a precancerous lesion characterized by submucosal fibrosis, reduced levels of vasculature, and mucosal atrophy. The clinical features of OSF include oral mucosal pallor and mucosal rigidity (Figure 3), which leads to limited opening of the mouth (Figure 4) (3). Consumption of products containing areca nut, such as supari, can play an important role in the onset and progression of OSF and cancerous lesions, and is therefore considered a

\footnotetext{
* Corresponding author: Masoomeh Shirzaii, Oral Medicine Department, Zahedan University of Medical Science, East Azadegan Street, Zahedan, IR Iran, Tel: +98-05412429483, Fax: +98-5412414003 , E-mail: Shirzaiy@gmail. com
}

DOI: $10.5812 /$ ijhrba.4177

Copyright $\odot 2012$ Kowsar Corp. All rights reserved.

\section{Please cite this paper as:}

Shirzaii M, Sarani M, Supari Consumption is a Common Oral Habit among Women in Chabahar City. Int J High Risk Behav Addict. 2012;1(1):44-5. DOI: 10.5812/ijhrba.4177

Copyright @ 2012 Kowsar Corp. All rights reserved.

high-risk behaviors $(2,3)$.

Consumption of products containing areca nut is common in Southeast Asian countries such as India, Bangladesh, and Pakistan $(1,4)$. In Iran, areca nut consumption is common in cities, such as Chabahar (South East of Iran), that are located near the border with Pakista. There are few epidemiological studies on the consumption of different areca nut products and the associated oral changes in the people of Chabahar (a city where areca nut products are easily available). In this study, which was conducted 2010, 1500 people, 1067 (71.1\%) men and 433 (28.9\%) women, (with use formulae of sampling size) who attended different health centers in Chabahar city were randomly selected and evaluated for consumption of areca nut products. To our knowledge, this was the first study was done in this field in southeast Iran. Among these subjects, 759 people, including 141 women and 618 men (age range, 8-48 years; mean age, $20-22$ years) were found to consume areca nut products (pan, supari, and guthka). The pattern of consumption of these products showed significant gender-based differences $(P<0.05)$; pan consumption was common among men (391 men, $51.5 \%)$, and supari consumption was common among women (135 women; 95.7\%). The women in our study believed that supari is beneficial for digestion and chewed 


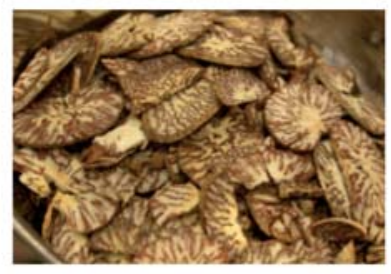

Figure 1. Areca nut

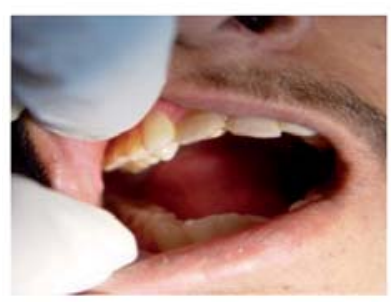

Figure 3. Rigidity of the oral mucosa

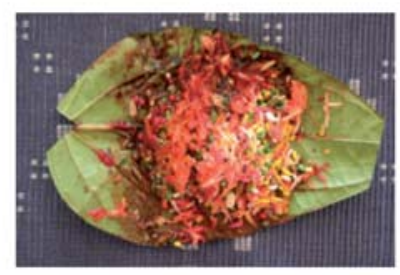

Figure 2. Pan

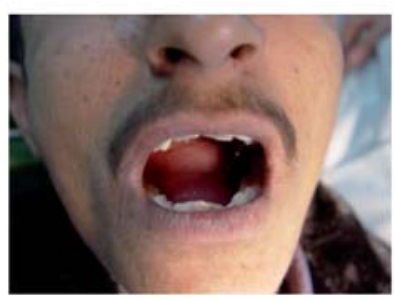

Figure 4. Severe limitation in opening the mouth

it repeatedly during the day some of them also believed that supari chewing has aesthetic value (because of the red color that supari imparts to the lips).

Further, our study showed a significant correlation between consumption of pan, guthka, and supari and the probability of occurrence of OSF $(P<0.05)$.

The rate of consumption of areca nut products and the associated prevalence of OSF and oral cancer in Chabahar is higher than elsewhere in Iran, because of the cultural factors and the easy access to areca nut products in this region. This city is located very close to the Pakistan

border, and areca nut derivatives are transferred across the border into Iran and are easily availableat very low. Moreover, because of the lack of adequate knowledge about the disadvantages of this substance, the natives of this region have the habit of chewing areca nut products; however, these products are rarely consumed in other parts of Iran. It is necessary to increase public awareness about the hazards of chewing areca nut products in this region and develop an immediate an appropriate program to achieve this objective.

\section{Acknowledgments}

We thank the Research Center of Zahedan Medical Sciences.

\section{Financial Disclosure}

Research Center of Zahedan Medical Science University.

\section{References}

1. Mehrotra R, Chaudhary AK, Pandya S, Debnath S, Singh M. Correlation of addictive factors, human papilloma virus infection and histopathology of oral submucous fibrosis. J Oral Pathol Med. 2010;39(6):460-4.

2. Reichart PA, Nguyen XH. Betel quid chewing, oral cancer and other oral mucosal diseases in Vietnam: a review. J Oral Pathol Med. 2008;37(9):511-4.

3. Ranganathan K, Devi MU, Joshua E, Kirankumar K, Saraswathi TR. Oral submucous fibrosis: a case-control study in Chennai, South India. J Oral Pathol Med. 2004;33(5):274-7.

4. Gao Y], Peng HY, Yin XM, Wen CY, Han YL, Xiao YB. [Epidemiological study of betel nut chewing among elementary and middle school students in Loudi city, Hunan province. Zhonghua kou qiang yi xue za zhi. 2009;44(11):686-9. 